\title{
1. Introduction: MNCs and their pathways of influence in global politics
}

\author{
John Mikler and Karsten Ronit
}

Multinational corporations (MNCs) have been active for a very long time in global markets and they also play a leading role in global politics, although the latter side of their activity has been far more contentious and often difficult to map. The traditional and dominant focus on states and their interests and strategies has generally marginalized the role of corporations, or at least the study of them. The result is that while some might be tempted to declare that what is and is not possible in global politics is an answer along the lines of 'it's the economy, stupid', ${ }^{1}$ it could be more accurate to say 'it's the MNCs, stupid!' The role of MNCs needs to be considered when analyzing key issues in contemporary global politics.

Of course, many alternative approaches exist, bringing the operations and interests of MNCs closer to our attention and informing research. However, scholarly work on MNCs tends largely to pull in two different directions. On the one hand, there is an economics and management literature concerned with analyzing the behavior of MNCs in terms of economic statistics and organizational forms. On the other hand, there is a politics and international relations literature that views their activities through the prisms of grand power politics. In the process, they go somewhat 'missing' between studies that detail a variety of economic and industrial properties of MNCs, versus those that discuss different dimensions of corporate power in terms of market forces, class relations, ideologies, national interests, international relations and so on. When it comes to political studies of MNCs the result is that 'instead of mountains of scholarly achievement, we have a few oases in an arid landscape' (Wilks, 2013, p. 2).

While acknowledging that the various analyses of MNCs' operations are enormously helpful and reveal important aspects of corporate conduct, the contributors to this collection aim to further bridge the extant scholarly cleavages to examine the many and intricate ways MNCs influence politics in the global realm. They combine firm-centered and institutional approaches and, as 
such, are concerned with identifying and evaluating the shifting roles of different pathways of influence employed by MNCs, highlighting major procedural patterns, rather than determining the ultimate power of business per se.

As a starting point, in this introductory chapter we note that MNCs have various established home bases, in addition to operations that are globally dispersed. They should therefore not be narrowly conceived as actors operating amorphously in markets, but as entities that exist in particular places and spaces and exercising political strategies in diverse institutional contexts. They also do not constitute a homogeneous category, with great variation possible between the economic and political profiles of different MNCs. Furthermore, there are a wide range of options available to them for seeking influence. At a very basic level, it is possible for single MNCs to administer their control of markets and, using this market authority, in some cases build specific relations with other key actors in their environment. In general, a range of relational arrangements with other MNCs in business associations, with the organized aspects of civil society, and intergovernmental organizations (IGOs) are also possible and pursued. The political options available to MNCs may also align with other small and large corporations, through which they form networks and associations and build other entities to coordinate interests in the business community and enhance their influence.

So, MNCs cannot be conceived as simply unitary actors. The networked attributes of their operations are central to their pathways of influence, as they manage supply chains and coordinate with subcontractors across multiple national jurisdictions. It is important to recognize this in research, and not perceive large MNCs as sufficiently strong to render collective action redundant. As their operations are spread globally, they must engage with various public authorities, including states and IGOs, to support regulation and encourage agendas that benefit their interests. If they find it necessary, they attempt to prevent public initiatives that threaten these interests. Their activities to influence global politics also include relations with the organized elements of civil society in multiple scenarios, which in many areas exercise what may be thought of as 'moral' authority. MNCs therefore take steps to address pertinent social and environmental issues, ward off various criticisms and build more solid relations. Sometimes they even establish joint institutions with civil society organizations $(\mathrm{CSOs})^{2}$ if they believe this to be required.

So, global politics is not a simple matter of states versus states, states versus private 'actors', or simply the pressures of particular individual MNCs. Instead, a range of actions and initiatives occur simultaneously and in a range of combinations that are hard to predict a priori. This implies that in the analysis of MNCs, we should conceive global politics in a fundamentally holistic way, rather than reducing our analysis to traditional policy processes organized 
around states and IGOs, with contending private actors nebulously exerting influence at the margins.

In the following sections of this chapter, we develop our framework for analysis. After seeking insights in existing research and highlighting how this book contributes to the literature, we show how MNCs are positioned in a greater and more complex system and how different contexts of influence must be considered. We then discuss the role of MNCs in relation to the political institutions of states, as well as to the business community and civil society, to formulate a framework for analysis that underpins the chapters to follow, prior to a brief outline of these.

\section{UNDERSTANDING THE ROLE OF MNCS IN AND BEYOND MARKETS}

MNCs are labeled as such because they invest, produce, and sell their products and services in more than one national jurisdiction. This is increasingly the 'normal' form that business takes. In 1970, there were around 7000 corporations that had foreign affiliates (Clapp, 2005), but by 2011 there were over 100 000, with nearly 900000 foreign affiliates (United Nations Conference on Trade and Development [UNCTAD], 2011). The geographical extensity of their operations has led some to label them transnational corporations (TNCs), placing them in a wider group of transnational organizations or non-state actors. This goes beyond conceiving them as operating in several jurisdictions to seeing them as passing across borders as if these were irrelevant. In other words, they rival nation states, potentially operating 'as if the entire world (or major regions of it) were a single entity' (Levitt, 1983, p. 92). The term multinational enterprise (MNE), most often used in the international business literature, also suggests transnationality, as it recognizes that corporations that operate across borders are not unitary actors but oversee and are embedded in networks. This is because modern business involves corporations that manage the operations of multiple other firms in supply chains, across multiple national territories. Yet, care must be taken to acknowledge all corporations' national anchoring, as well as their international and sometimes global presence. This is not some mere hair-splitting exercise, because it matters politically and may influence their various pathways of influence, particularly the ways in which they combine national and global actions. Therefore, it is analytically important to see corporations as first MNCs, before they potentially exhibit aspects of TNCs or are involved in MNEs. While a multinational dimension to almost all major corporations is now taken for granted, where and how MNCs express and pursue their interests is still ill-defined and underexamined. And this is what the contributors to this collection examine. 
These issues are important to examine because, according to commentators like Korten (2015; see also see Harrod, 2006; Kollman, 2008; Zadek, 2013), MNCs are among the most, if not the most, important political, economic and social actors in the world. Given their command over resources, and relations with not just their employees but stakeholders in society more broadly, they may be more important for addressing the challenges faced by the world than a range of nation states. Others think that they may actually be taking over the role played by states, to the point that studies of state sovereignty should be accompanied by a focus on corporate sovereignty (e.g., Barkan, 2013). Their importance, the role they play, and their pathways of influence are questions worth considering, and yet up to now it still seems reasonable to say that they significantly go 'missing' in studies of domestic and global politics.

What is usually done is that their motivations are assumed in material terms, and therefore their actions are determined on the basis of the assumptions made about their interests. Underdrawn as primarily 'market actors', they are ascribed economic motivations (e.g., see Broome, 2014). This view represents a reductionist approach, and one that is not particularly accurate when groups of firms come to dominate rather than compete in markets. A major reason for this individualized, economic, market-focused understanding of MNCs is no doubt that major theoretical inspiration is taken from the economics tradition, where 'the firm' takes center stage and is assumed as the unit of analysis. This atomistic view is carried over into other social sciences, resulting in an under-institutionalized approach to corporate behavior. Of course, it is not that this is necessarily wrong, but the political motivations of MNCs and the political influence they exercise in the various contexts in which they operate are underplayed in much analysis as a result. Sometimes they are even absent.

Related management and business administration studies have also colored approaches to research on MNCs. These traditions are concerned with the organization and diverse strategies of single corporations with, again, a key emphasis on their behavior in markets. Indeed, the strong focus on corporate social responsibility (CSR) since the 1990s, and a quite vast literature that now surrounds it, is part of these different management traditions that today also spill over into MNC research in different areas of sociology and political science. But this interest in corporate behavior rarely addresses the potential power of corporations in society, or the relations of business with political institutions. As Wilks (2013, p. 210) puts it, CSR is 'not just a struggle over practices, but one over the locus of governance authority', and yet it remains rarely discussed in these terms. It should be because, due to their size and territorial reach, they are not the simple servants of markets and market forces but controllers of them.

The result of these one-sided views on MNCs is that broader questions about their pathways of influence are sometimes not asked at all. Or if they are, then 
questions about the nature of MNCs' actions, as well as the motivations for them, are answered before they are asked. This is more or less done along the following lines. We live in a globalized world in which policies of privatization and deregulation have undermined the role of the state to the point where all forms of political and social interaction have become marketized. States must don neoliberal 'golden straightjackets' (Friedman, 2000), because MNCs are unconstrained by borders, while the governments of nations are. If the interests of MNCs are not served, they will go somewhere else, and therefore states tend to become 'competition states' with the policy objectives of 'the promotion of free enterprise, innovation and profitability in both the private and public sectors' (Cerny, 2000, p. 302; see also Cerny, 2010). Taken to the extreme, all states will inevitably come to perform in such a manner over time, and MNCs are seen as slipping their territorial bonds to such an extent that they are "no longer dependent clients of their home states and the new global partnerships between states and corporations are more likely to be manifest in collaborations in transnational networks and sharing in regulation and economic governance' (Wilks, 2013, p. 166). Accordingly, the result is that we live in a world of a neoliberal order that benefits market actors like MNCs, and neoliberal disorder that impacts the efficacy of national, democratically representative government and governance (e.g., see Cahill, 2014; Teeple and McBride, 2011).

Now, all this may be true to one degree or another, and depending on what the issue is that is being considered. But rather than stressing the power of market 'forces' that must be obeyed in a globalized world, and for which MNCs are merely the conduits, it is important to look at the politically motivated actions of MNCs with regard to other actors. Corporations are not zombies responding to market imperatives, or eating states and their societies' 'brains', but an organizational form employed to act on the demands of shareholders and various key actors in their environment. Therefore, there are a range of factors that necessitate an analysis of their more subtle pathways of influence. They should not be underdrawn as purely economic actors any more than states should be seen as purely political, or citizens and civic groups as purely social. The reality is rather this: there are enormous and powerful MNCs, there are states that contrary to the early globalization literature are not 'dying', and there are societies comprising citizens who are organized, and who demand governance in their interests rather than disembodied forces that are 'out there' and impacting on them like meteors on the face of the Earth.

The world has come a long way from the scenario Adam Smith imagined of entrepreneurial individuals and their firms competing on the basis of the market's 'invisible hand' rather than the visible hand of the state. ${ }^{3}$ According to Nolan, Sutherland and Zhang (2002), by the end of the twentieth century, no more than five global corporations controlled each of the world's major 
industries, with around a third of these having one corporation accounting for more than 40 percent of global sales. According to Tepper and Hearn (2019), this concentration of oligopolistic to monopolistic power has increased in the years since then. As Crouch (2011, p. 49) observes, there has been a 'corporate takeover of the market' by these enormous entities. The situation we have today is not the invisible hand of the market that attacks or modifies the visible hand of the state, but instead a visible handful of global corporations.

With the dominance of their markets comes immense potential for corporate engagement in politics. MNCs' size alone shows this to be the case. In 2018, the Fortune Global 500 companies together had sales totaling US\$32.7 trillion (Fortune, 2019). Given that the size of the global economy was estimated to be US\$85.9 trillion in the same year (World Bank, 2019), this means that they effectively accounted for 38 percent of it. In fact, the sales of the world's 20 most global MNCs are greater than the combined gross domestic product (GDP) of the bottom 138 states, and greater than the combined expenditure of the bottom 166 states (see Mikler, 2018, p. 8; based on UNCTAD, 2014 and International Monetary Fund, 2015). And their sales versus the GDP or expenditures of states are a good measure, rather than that of value added that economists would use, because these corporations are best seen as networks. For example, Walmart does not own any manufacturing operations but contracts over 100000 suppliers that produce the products it sells (LeBaron, 2014; Walmart, 2013, 2017). Other MNCs like Apple, Gap, and Nike also produce no goods themselves. Instead, as a result of the intellectual property they own for the products they design, their core function in the production process is the contracting and logistical management of their global supply chains. They sit atop these chains, coordinate them, and therefore embody the value added of the firms that they contract within them.

This a large part of the reason trade data does not reflect exports and imports between states, but the strategic decisions of the management of MNCs coordinating their supply chains. Of course, trade data has long been dominated by firms, but the point is that it is now dominated by MNCs. This means that the trade data for manufactured goods does not represent finished products, but movement within MNCs' global supply chains. Even by the 1990s, up to 70 percent of trade in manufactured goods between Organisation for Economic Co-operation and Development (OECD) countries was intra-firm, rather than inter-state, in nature (Bonturi and Fukasaku, 1993; see also Karliner, 1997). The data on financial MNCs tells a similar story of concentration and control. Seventy percent of the banking market in OECD countries is accounted for by their largest three banks (OECD, 2014; see also Beck, Kunt and Levine, 2005), while globally 14 banks dominate foreign exchange rate markets and ten dominate global options markets (OECD, 2011). In 2017, the world's top 
ten banks had combined assets of over US\$28.3 trillion (Banks Around the World, 2018).

These insights are helpful in guiding us when analyzing the role of MNCs in global politics. We know the MNCs' names, we know their size relative to states, and we therefore need to study their dominance of the global economy and their political pathways of influence in respect of it. They do this in many ways: in their own right and in relation to states, IGOs, the business community at large and civil society (see Figure 1.1).

\section{INFLUENCE IN THEIR OWN RIGHT}

Influence in their own right is the first pathway of MNCs' influence. The potential for this is the starting point from which the other pathways flow, and it comes from the key authority that MNCs hold in markets. This is a private authority that is both won and defended by MNCs themselves, but also granted and solidified by public authority. It does not come out of thin air, as, most basically, MNCs' influence 'in their own right' rests on the authority to hire and fire, and the authority to set prices and to invest. But this is not a completely unalterable state of affairs, and corporations must proactively work to keep this authority. Political considerations are therefore involved, but the political place and space occupied by corporations, and for our purposes MNCs in particular, are not straightforward. They operate at and above the level of nation states, yet they obviously have relationships with states and their societies, as well as IGOs and CSOs, rather than operating in a vacuum.

Given the emergence of new forms of cooperation as a result of such relationships, what has been labeled the 'three faces of power' framework can be useful for understanding the pathways employed by MNCs in their own right with regard to these other actors and in their institutional environments. Such a framework was originally employed in the theoretical politics literature to states and political actors in general. However, attempts have been made to employ it specifically to understand global business power (Fuchs, 2007; Mikler, 2018). As such, it can provide inspiration to analyze how MNCs work to influence agendas through employing instrumental power, and potentially set agendas through their possession and exercise of structural and discursive power.

In a simplified version, instrumental power focuses on the direct influence of one actor on another to achieve a desired outcome (Dahl, 1957, p. 201). This is done through inducements in the form of rewards or threats, and so instrumental power is about leverage exercised to achieve a desired end (i.e., it is instrumentally motivated). In terms of MNCs' pathways of influence, it is most clearly seen in efforts to directly influence policy-makers to produce desired outcomes. There are many examples of the extensive political efforts 
of corporations, and the associations to which they belong, leveraging political institutions at the national and international levels. Some have likened the relationship as akin to a revolving door, in the sense that the interactions are so pervasive and extensive that the barrier between what is public and private seems to no longer apply (e.g., see Davies, 2015).

The explicitly relational aspect of the first face of power suggests that there are fundamentally territorial aspects to it. This is because although corporate interests and operations may be increasingly multinational, instrumental power must be exercised somewhere, and often at multiple territorial levels. Such territoriality is potentially less the case for the second structural face of power, and this is therefore where MNCs can really exert influence in their own right. This is because structural power emphasizes the way issues are organized 'in' and 'out' of politics due to political actors' capacity for agenda-setting. As Bachrach and Baratz (1962, p. 948) explain, it means 'A devotes his energies to creating or reinforcing social and political values and institutional practices that limit the scope of the political process to public consideration of only those issues which are comparatively innocuous to A' (see also Strange, 1988). In respect of business, this suggests the possession of underlying control of processes and resources. MNCs certainly possess such control. As noted above, their size and dominance of global markets that are overwhelmingly oligopolistic to monopolistic means that they are in a position to punish or reward states for the provision of (un-)favorable conditions. This is true both within, as well as between, their territories. This further means that in addition to enjoying a revolving door relationship with policy-makers, they are in what has been termed a privileged position by comparison to other private actors in society (Lindblom, 1977; see also Cox, 1987; Culpepper, 2011; Frank, 1978; Tienhaara, 2014). Their voice is not just one in a range of competing interests. Instead, MNCs' indispensability to the economic bases of states and the global economy, and the control they can exert across levels from the local to national to international, means that sometimes they can get what they want without even asking for it. Their business interests are inevitably considered.

If this is indeed what happens, then the strongest position they can hope to be in is one in which their concerns do not just have to be taken into account but also deserve to be so. This brings us to the third face of discursive power, which focuses on the role played by ideas. It is the hardest to observe, because it relates to the creation of one political actor's interests in another. As Lukes (1974, p. 23) once explained, 'A may exercise power over B by getting him to do what he does not want to do, but he also exercises power over him by influencing, shaping or determining his very wants'. It is therefore not just about getting desired outcomes, but about the right to get them. If power is 'the production, in and through social relations, of effects that shape the capacities of actors to determine their own circumstances and fate' (Barnett and Duvall, 
2005, p. 39), then this is surely the most powerful face of it. It is about ideas that become valid at the domestic and global level and penetrate society, essentially creating 'truths' about policy. This allows MNCs to promote the 'projection of a particular set of interests as the general interest' (Levy and Newell, 2002, p. 87). Discursive power may even underpin perceptions of legitimacy. Not legitimacy per se, but legitimacy in the sense of discursive legitimacy (Mikler, 2018), as it creates 'a generalized perception or assumption that the actions of an entity are desirable, proper, or appropriate within some socially constructed system' (Suchman, 1995, p. 574).

Of course, in reality, political power is not so easily divided up as discussed here. The different faces of power have many and intricate relations, and because they are often so integrated, they can be difficult to entangle, map and analyze. Yet, the division has heuristic value because it serves to suggest the nature of the pathways of influence produced. Indeed, discursive power that leads to legitimacy reinforces instrumental and structural power by institutionalizing widely accepted norms of behavior on the basis of it. It may even shape widely accepted beliefs as self-evident about the nature of globalization and the operation of the global economy, such as the widely believed 'truth' of the desirability of free and deregulated markets that underpins corporate power. What is considered legitimate at the national level may potentially also be transferred to the global level. This can benefit MNCs as they can increase their economic, political, and social control not just in the states where they are headquartered, but wherever they operate and have interests. To understand these processes, we therefore have to examine in further detail how MNCs interact with governments and other public institutions at the level of the state, and beyond it, in support of their interests.

\section{INFLUENCE PATHWAYS AND STATES}

Corporate influence and states is the second pathway of MNCs' influence in global politics examined in the book. This relationship addresses the question of whether MNCs just rely on their home states to have their interests represented in international contexts, or whether MNCs must be active themselves at international levels and take a relatively independent role. No doubt the answer is both, and therefore a matter of degree contingent on a range of factors, but even so, territory still matters to MNCs as it does to the governments of nations. Therefore, the exercise of their power at this level must be studied as a distinct pathway.

There is a wealth of prima facie evidence for this, such as the research of Rugman and Verbeke (2009), who demonstrate that only nine of the Fortune Global 500 MNCs have sales in so many regions of the world that they may be regarded as truly global. Three hundred and twenty of them still derive 80 
percent of their sales from their home region, while for the others, 25 are more accurately defined as bi-national or bi-regional on the basis of their sales. The same may often be said of where their productive assets are located. For example, authors like Voss (2013) have noted that corporations headquartered in Taiwan and Hong Kong are often MNCs on the basis that their manufacturing capacity is located in mainland China, but nowhere else. In reality, they are therefore more accurately regionally Chinese corporations as opposed to MNCs.

Similar observations have been made in respect of ownership and control. For example, an analysis by Staples (2007) of the world's 80 largest MNCs demonstrates that no more than 25 percent of their board members comprised those of another nationality to the corporation's headquarters. Only for 10 percent of them were the majority of board members from another nationality. This study is supported by others done on a regional basis, such as van Veen and Marsman (2008) for European MNCs specifically. These studies were done around a decade ago, and it could be claimed that there is a tendency over time towards greater multinationality on the part of board members as there are in corporations' operations. Yet, these studies also demonstrate that the main way corporate boards become more globalized is through mergers and acquisitions, not always as a result of the geographical spread of their activities.

It should therefore not be as surprising as some may find it that economically powerful states still account for 80 percent of world output, 70 percent of international trade, and up to 90 percent of foreign direct investment (FDI) (Chang, 2008, p. 32). This is because it is the MNCs from these states that do so. This is likely to have a bearing on their pathways of influence. In addition, the proliferation of MNCs also enables them, and potentially their home states' governments, to move beyond domestic boundaries in an attempt to influence foreign governments. This is because they are not placeless entities. Just ten states are the headquarters for 84 percent of them. The US alone accounts for 42 percent (Financial Times, 2016). With the emergence of Brazil, Russia, India, and China (collectively known as the BRICs) as economic powers it may no longer be as true as it once was that 'a statistical profile for the current corporation indicates that it is predominantly Anglo-American' (Harrod, 2006, pp. 27-8) - although lately, it is looking a lot more Chinese - but it remains the case that the home bases of the world's largest corporations are like a map of global economic power (e.g., see Mikler, 2018). As the global economy is said to be geographically triadic, so are the main headquarters of the world's major MNCs. Hence, the close correlation between the national economic and corporate data: the FT Global 500 are responsible for at least 80 percent of the world's stock of FDI, around 70 percent of world trade, and 30 percent of the world's GDP (Rugman, 2000; see also Bryant and Bailey, 1997). 
The relationship between MNCs and states has important implications for global politics. It is not just that there is a relationship between national economic and corporate data but also that, as noted above, trade statistics reflect intra-firm, rather than inter-state patterns of economic interconnectedness. This gives MNCs a key role in relation to states, because rather than trade occurring on the basis of Ricardian comparative advantage, and on the basis of merchants 'preferring the support of domestic to that of foreign industry' (Smith, 1776 [2003], p. xvii), it instead occurs on the basis of competition between the suppliers of intermediate goods and services to MNCs. And these MNCs govern through contractual, and indirectly subcontractual, arrangements and rules how the global economy and trade relations are structured. In many ways, they are engaged in shaping government strategy and impacting the sovereignty of the states where these suppliers are based, as well as those where they are headquartered, and they are able to confer the benefits of employment and economic growth on these states, or remove them.

The result is that they are in a position to influence the rules of commerce and social and political relations across, as well as within, national territorial boundaries. Of course, influencing governments is crucial for MNCs when active in national markets, but strong relations are also important when following up on rules adopted at the global level, or when governments are formulating positions to be prosecuted in international fora. Therefore, the pathways of influence between MNCs and states are not solely confined to the national level and national institutional contexts. MNCs are also important players in global politics, including in the deliberations and agreements made in IGOs.

\section{INFLUENCE PATHWAYS AND INTERGOVERNMENTAL ORGANIZATIONS}

Corporate influence with IGOs is the third pathway of MNC influence and, like relations at the national level, how we conceptualize this is not straightforward. Capitalism is global and MNCs are some of the key actors that help make it so, but, as suggested above, the sources of their power are located at different levels, varying from country to country. They also may vary from industry to industry and from issue to issue. It would therefore be erroneous to radically re- or de-territorialize the political pathways employed by MNCs. Any analysis must necessarily be complex as a result, yet there is a simple point that may be made in respect of it - that is, if MNCs express their political power, they must do so in multiple places and relationally with multiple actors at different levels, from the local to national and international levels.

This is a contested area of study though. On the one hand, there are claims that, increasingly, corporate influence is seen at the highest of these levels to move downwards to lower levels, rather than produced at lower levels to be 
manifested at the highest level. This is essentially Büthe and Mattli's point, who observe that 'the view that most regulatory issues start out as domestic problems before globalization makes them international issues underplays the fact that a good deal of transnational regulation is motivated by uniquely transnational problems; and that transnational institutional structures may offer privileged access to some actors, biasing global regulatory outcomes in ways difficult to comprehend from a purely domestic perspective' (2011, p. 9). On the other hand, there is the view that corporate influence essentially flows more the other way. For example, Harrod (2006, p. 34) stresses that 'the international or global power of the corporation is more a function of the power it has achieved within powerful headquarter states'. Therefore, 'to focus on the study of the global activities of the corporation means to study the point of entry rather than the source of its power and activity'.

An emblematic and much cited example of the debates around this in practice is the negotiation of the Trade Related Aspects of Intellectual Property Rights (TRIPs) agreement in the World Trade Organization (WTO). Approximately a dozen US MNCs formed the Intellectual Property Committee (IPC), a cross-sectoral business alliance, with the purpose of extending the rights that they enjoyed in the US to the world. However, they did not just work at the national level in leveraging the US government and its representatives in the WTO. Executives from these MNCs also engaged their European and Japanese counterparts to influence their governments for a strong TRIPs agreement. The result is that by working with each other internationally, as well as at their respective national and regional levels (in the case of the EU), these MNCs presented both a powerful united front in their own right, and were assisted by negotiators who pushed for 'globalizing enforceable intellectual property standards' (Braithwaite and Drahos, 2000, p. 71). In her analysis of this process, Susan Sell (2003, p. 96) concludes that the result is that they ultimately 'made public law for the world'. But did they make it in the WTO through various states to affect the rules adhered to by others? Or did they take arrangements existing at various national levels and through their relations with their home states shift them upwards to the global level? Perhaps they did both, and we can simply say that the CEOs of these MNCs acted together and with their home states' representatives in an IGO to achieve the goal they desired.

As a general rule though, MNCs and their executives do not enjoy consultative status with IGOs. Some IGOs do not formally engage with non-governmental organizations of any kind, but those that do prefer formal relations with representative organizations, such as business associations. This practice is related to the original UN Charter and is used in many intergovernmental organizations within or beyond the UN family. It states that: "The Economic and Social Council may make suitable arrangements for consulta- 
tion with non-governmental organizations which are concerned with matters within its competence. Such arrangements may be made with international organizations and, where appropriate, with national organizations after consultation with the Member of the United Nations concerned' (United Nations, 1945). This suggests that MNCs' relations with UN agencies either go through states as members of these bodies, or through associations or similar entities in business. For MNCs this is a strong incentive to work through these pathways of influence.

In some cases, exceptions are made to this rule. The best-known example is the UN Global Compact where single corporations are members, giving them a unique opportunity to shape global policy. This design clearly broke with established traditions for consultations, much to the dismay of many other IGOs that see strong value in building relations with private organizations that can speak for broader interests, and not those of individual corporations. An example of this practice is the International Organization for Standardization (ISO). Individual MNCs cannot be members of the ISO, but nor can states. Instead, the ISO's membership comprises 163 national standards associations, the membership of which includes industry associations, government organizations, standard-setting and conformity assessment bodies, trade associations, labor unions, professional societies, consumer groups, and academia (ISO, 2016a, 2016b).

As there are subnational, national, regional, and global aspects to the dissemination of the ISO's standards via its membership, so too are there political implications in the sense of its operations and whose interests it represents. As such, the pathways of influence of MNCs figures in understanding this, even if they are not individually directly members of it. As the ISO increases the scope of its activities beyond technical production standards, to standards in management (ISO 9000 series), the environment (ISO 14000 series), and social responsibility (ISO 26000 series), MNCs have seen an opportunity to reduce the potential proliferation of multiple national standards in these areas (Clapp, 1998). They have used their influence at multiple levels to create standards across borders that 'become de facto requirements for doing business around the world' (Haufler, 2000, p. 128), and that are in their interests.

When MNCs succeed in ensuring their interests are not just considered but pursued by IGOs, they are potentially in a position not just to influence but also to set global agendas. The growing role of corporate interests in the United Nations illustrates the point. A study by Seitz and Martens (2017) considers the role of corporate funding for UN initiatives. These include funding projects to improve access to water, water quality and water management for the United Nations Development Programme (UNDP); HIV AIDS education for the United Nations Educational, Scientific and Cultural Organization (UNESCO); and support for the UN Women Private Sector Leadership Advisory Council, 
which is chaired by the CEO of Coca-Cola. In addition, philanthropic organizations, like the Bill and Melinda Gates Foundation, are responsible for around 10 percent of all aid flows under the OECD's Development Assistance Committee. In fact, in 2014 the Bill and Melinda Gates Foundation was the second highest funder of the World Health Organization after the United States of America. This may be desirable if funding is available for important international programs in respect of a range of economic, environmental, and social concerns. However, it does raise concerns in respect of transparency and accountability related to the motivations for MNC involvement in these programs - for example, if they are not motivated by strategically addressing the issues as opposed to enhancing corporate reputation. The problem, therefore, is that there is 'a growing reliance on corporate-led solutions to global problems' (Seitz and Martens, 2017, p. 46) as MNCs are increasingly not just influencing the agendas of IGOs but defining and funding them. This shows that in addition to many traditional contacts and pathways, new and hitherto less explored avenues need to be examined. This includes those within the business community itself.

\section{INFLUENCE PATHWAYS AND THE BUSINESS COMMUNITY}

The fourth pathway in our study embraces the business community in its widest sense, as this is institutionally remarkably diverse, and is organized at both national and international levels, creating multiple linkages across territories. If MNCs are not isolated actors standing alone in the market, nor exerting political power in isolation, then it must be the case that they interact with many other entities in the business community. By drawing on existing literatures on $\mathrm{MNCs}$ - including management, economics and international political economy - we can improve our understanding of corporate influence (Greif, 2005; Hollingsworth and Boyer, 1997; Lawton and Rajwani, 2015), but it is not only a matter of assembling already known parts to form a more coherent whole. In the business community, a large universe of organizations in the form of, for instance, cartels, clubs, associations, and other networks, are available to MNCs and need to be mapped and understood to analyze the pathways of MNCs' influence. Through these entities, MNCs are able to coordinate with each other as well as with other firms.

These different forms of coordination are shaped in national as well as in international and global contexts. The varieties of capitalism literature is helpful in identifying national institutional variations (Hall and Soskice, 2001). For example, some states rely more on non-market modes of economic coordination, including between firms, organized labor (i.e., unions), and government, while others stress an arm's-length relationship between government 
and business, and promote the role of unfettered market forces. We accept that this is the case, while recognizing that it can also be argued that there is generally much more similarity between the 'capitalisms' than is often stressed (e.g., see Streeck, 2011). In this sense, there are varieties or variations in, as well as $o f$, capitalism (Hay, 2019). But more fundamentally, there is a tension between stressing the different national institutional contexts for business, versus the idea that with the rise of MNCs, a specific and relatively independent global business community has been created that is not necessarily as nourished by a multiplicity of national institutional traditions, nor as defined by national borders, as was once the case.

One result of this is that collective action through national business associations is not needed in all areas of business for MNCs to coordinate their activities. In some cases, it is possible for large MNCs to act together in specific 'clubs' for business leaders, or to coordinate with other elites outside the business world. A well-known example is the World Economic Forum (WEF), which has no national chapters but has a long list of MNCs as members on a direct basis (Ronit, 2016). Yet, it remains the case that at both the domestic and international levels MNCs, owing to their role in the market, are in a position to wield strong influence on organizations in the business community. When competition leads to economic concentration, MNCs become dominant in many sectors of the economy and in many parts of the value and production chain. Thus, as noted above, many industries are today dominated by a relatively small number of firms. This concentration enables very large corporations to act on their own, as national 'champions' at home but also at the global level. Furthermore, such patterns of market hierarchy are likely to have an effect on the character of cooperation with other firms and can have an important impact on the resources employed to influence politics. These different individual and collective options, however, do not exclude each other but can be combined in many ways. For example, the development of single MNCs with significant resources can facilitate the formation of individual strategies and encourage independent action, of which the tech giants are prominent examples. And firm-centered studies in economics and management, being focused as they often are on the organizational strategies of individual firms, are inclined to emphasize the opportunities for them to do so (e.g., Funk and Hirschman, 2015; Hillman, Keim and Schuler, 2004; Lawton, McGuire and Rajwani, 2013; Windsor, 2007). However, we cannot extrapolate and conclude that MNCs will, with increasing size, necessarily act alone, shunning alliances with other firms. In some cases where few corporations come to dominate a global industry, cooperation between otherwise strong competitors may seem a more logical choice, and they benefit from the advantages of small group size in doing so (Olson, 1965). 
It is difficult to predict the concrete consequences of dynamics in the market for cooperation in the business community, but, as already mentioned, we anticipate that various asymmetries will spill over into social and political forms of exchanges. Therefore, a more detailed analysis is necessary to reveal the quite extensive concerns managed by organizations in the global business community, and the opportunities they offer MNCs. To fully appreciate how these mechanisms work, however, we must differentiate between a variety of organizations in the global business community (Ronit, 2018). Some organizations seek to formulate strategies to influence traditional public policy adopted by IGOs, with the International Chamber of Commerce as a prominent example (Kelly, 2005), while others define and implement regulation without the involvement of public authority at all. For example, beyond the ISO there are many other standard-setting organizations that are completely private in their membership (Hale and Held, 2011). Some work to represent the general business voice, maybe even with the ambitious goal to speak for the 'capitalist class' as such (van der Pijl, 1998), while others are concerned about the organization and representation of specific industries with specific interests. Some are focused on delivering various services to enhance the competitiveness of corporations but also assist with strategy building, as demonstrated by the role played by the Big Four consulting firms (Morgan, Sturdy and Frenkel, 2019), while others are interested in setting agendas and improving the reputation of companies, as we have seen in the all-encompassing CSR movement. It is beyond the scope of this chapter to identify all the different subsets of actors and organizations active in the business community, but it suffices to say there is immense variety in their forms and purpose. It is also important to note that, in addition to working with states, they often work directly with CSOs.

\section{INFLUENCE PATHWAYS AND CIVIL SOCIETY}

This is the fifth and last path of influence considered in the book, because to develop an approach spanning the diverse paths of MNC influence in global politics we must consider not just the way that MNCs organize and influence each other and states, but also the relations MNCs have with organized civil society. Just as firms have become MNCs, so too has civil society experienced a significant degree of globalization (e.g., see Scholte, 2005). Therefore, MNCs increasingly encounter CSOs at both the national and international levels. When civil society is organized at different territorial levels there are ample opportunities for them to coordinate and link domestic and international activities. Although it is not the case that all CSOs exist to confront and challenge business behavior, when they do, patterns in the challenges they mount may be observed. On the one hand, civil society can pose a serious challenge to MNCs and question their strategies and practices. Indeed, CSOs can develop 
into serious countervailing powers, and through various forms of activism ultimately address the power of corporate influence in global politics (Dauvergne and LeBaron, 2014). On the other hand, civil society may in some cases become partners with business in the solving of specific problems, sometimes with the risk of CSOs losing their identity and independence (Roberts, Jones and Fröhling, 2005), as they build alliances and partnerships that may enhance the influence of business (Ronit, 2007). In relation to civil society, various pathways of influence are available for MNCs, but much depends on the strategies of CSOs and the willingness of MNCs to either work with, respond to, or oppose them. In general, however, it seems that MNCs must learn how to deal with critical voices in civil society and adjust their strategies. The whole development of the CSR movement in business can be seen in this light, but then this raises the question of whether or not the resulting initiatives are mere acts of 'window dressing', or in the case of the environment 'greenwashing', as opposed to real changes in behavior (Bowen and Aragon-Correa, 2014; Ramus and Montiel, 2005).

The CSOs themselves are located in different positions, not just geographically, but with regard to MNCs specifically. Some are closely linked to MNCs' production and value chains and represent interests that corporations can enter into direct contractual relationships with, such as unions or consumer groups, but this does not always lead to arrangements with business in a partnership sense (Cumbers, Nativel and Routledge, 2008; Stevis and Felli, 2015). Furthermore, other groups such as environment and human rights movements, which do not formally represent actors in the market with whom MNCs conclude contracts, nevertheless may influence the nature and terms of these contracts. For example, environmental standards or regulations in respect of labor rights are often promoted by CSOs, sometimes aligned with or represented by consumer organizations or labor unions, and therefore these CSOs may achieve a stronger position in relation to corporations (Ruggie, 2013). In turn, these dynamics in the civil society community are important in (re-)defining the strategic thinking of MNCs. The result is that we must be careful not to see possible interactions between MNCs and civil society exclusively as a set of bilateral relations, as the different pathways of influence are intertwined. In many cases, CSOs pose a challenge to corporations when they influence governments and IGOs to encourage the global regulation of business in many policy fields (Braithwaite and Drahos, 2000; Stone and Maloney, 2019). Influencing political parties and government agencies at domestic levels also become crucial in this context. This is, for instance, the case in areas where principal authority is nested in national public institutions, such as tax policy (Eccleston and Elbra, 2018; Palan, Murphy and Chavagneux, 2010; Rixen, 2011). 
We must also be careful not to narrow down the analysis of CSOs and business to exchanges in, or close to, the market. Although markets are a key focus of corporations, as noted above MNCs are in a position to control markets, and they are political actors that can be influenced by many other processes in their environment. Therefore, as CSOs strive to set agendas and change public perceptions, they can build moral authority that gives them certain advantages in relation to MNCs' interests. As argued by Vogel (2005), CSOs have the ability to provide MNCs with what can be regarded as a 'social license' to operate. They can also withdraw it. Mining is a key case in this regard, as the operations of MNCs in this industry are geographically fixed and therefore vulnerable to the displeasure or criticism of CSOs. Conflicts are therefore frequent (Moffat and Zhang, 2014), and organized civil society has in some cases been influential in changing corporate practices (Bloomfield, 2017).

CSOs launch various campaigns that are sometimes targeted at an industry, or sometimes at individual MNCs whose behavior is deemed immoral, and they urge them to change their practices (Yaziji and Doh, 2009). Sometimes MNCs can ignore such campaigns, but not always. As a major environmental organization, Greenpeace managed to influence the toy company Lego to terminate its contract with Shell (Vaughan, 2014), considered an irresponsible company in respect of environmental and climate change issues. In many ways, various CSR initiatives can be seen as a response, or a pre-emptive measure to forestall influential civil society. MNCs, thus, have many ways to maintain or extend their influence adapting to dynamic changes in or beyond the economy.

In a number of cases, however, the active presence of civil society can be an important opportunity as well. Many initiatives in civil society have an integrative character, in the sense that they seek to involve business in joint rule-making. For example, various CSOs appeal to business to join standard-setting schemes on a voluntary basis in areas where no proper public regulation exists (Abbott and Snidal, 2009; Lambin and Thorlakson, 2018; Porter and Ronit, 2015; Toffel, Short and Ouellet, 2015). The significant rise of such schemes has received strong attention in the study of business and politics, and they are studied under different concepts, but the perspective of MNCs and their pathways of influence are always involved. In fact, these schemes may bring some benefits to those MNCs that are more efficient and more willing to comply with rules, as this will sharpen their profiles in competition and as a result leaders will tend to outcompete laggards, an issue that has been much discussed in relation to the development of climate-friendly technologies (e.g., Gunningham and Sinclair, 2002). Initiating or joining such schemes, even pioneering them, may improve the overall reputation of the MNCs involved. 
Such arrangements therefore often have a multi-stakeholder character and are neither exclusively civic, nor corporate. They also offer opportunities for participating MNCs to influence the rules they adopt. Although some schemes are very close to self-regulation adopted in the context of business associations and specialized clubs, where MNCs have a significant input, they have often emerged under the impact of civil society, as is, for instance, shown in the case of the Global Apparel Coalition, an initiative embracing a range of MNCs in the apparel industry (Kozlowski, Searcy and Bardecki, 2015).

From the perspective of MNCs, it is crucial that they manage to respond effectively to different challenges from civil society, and if necessary, thwart or join civil society initiatives, one of the many pathways to influence. However, we need to emphasize that there is a range of areas where there is no real struggle over agendas between business and civil society. Given the private authority of business, there are simply areas and decisions that corporations control and that are taken for granted and are very hard to wrest from the hands of corporations. In addition, MNCs usually dispose of significant resources and expertise that makes it comparatively harder for CSOs to mobilize interests and formulate alternatives in the global realm.

\section{A FRAMEWORK FOR ANALYSIS AND THE CONTRIBUTIONS TO THIS VOLUME}

We have identified five different pathways of corporate political influence based on the foregoing discussion, and these are indicated in Figure 1.1. It shows that MNCs may act on their own or together (hence the double vertical arrows) and in different institutional contexts (hence the boxes). First, individual MNCs, and for that matter groups of MNCs, can be seen as political actors in their own right. They wield authority as well as compete in markets, and make key decisions to hire and fire workers, invest in productive capacity, and contract other firms. They are also in a position to deliberately employ significant economic and political resources to influence other private and public actors in their environment. Second, MNCs are in a position to influence governments in their home states that make regulations and in various ways that shape the overall conditions for business. Their home states may further the interests of these same corporations in international settings when assistance is needed, especially when these interests are shared between states and MNCs. The same potentially goes for the states in which they invest and operate abroad. Third, and relatedly, MNCs need to closely follow and influence many different international agendas that may have an impact on the conditions under which they operate. Therefore, they provide input to agreements negotiated in IGOs that will affect their work at the international level. This implies building expert knowledge and solid relations with the relevant IGOs. 
Fourth, MNCs have an important place in the business community. While MNCs can act on their own, they are also involved in setting norms and rules through various contracts and coordinating mechanisms, including business associations and self-regulatory bodies that govern behavior in the business community and represent interests before other actors in, and beyond, markets. Finally, MNCs engage with both critical and supportive voices in civil society that challenge and modify their behavior. In some cases, agreements and rules are produced through cooperation that eventually may grant corporations stronger legitimacy and enhance their social license to operate. It is important to note that these different pathways for political action can be employed separately. However, depending on the preferences and opportunities available at a particular time, in a particular situation, or in respect of a particular issue, they often tend to be combined (hence the horizontal arrow).

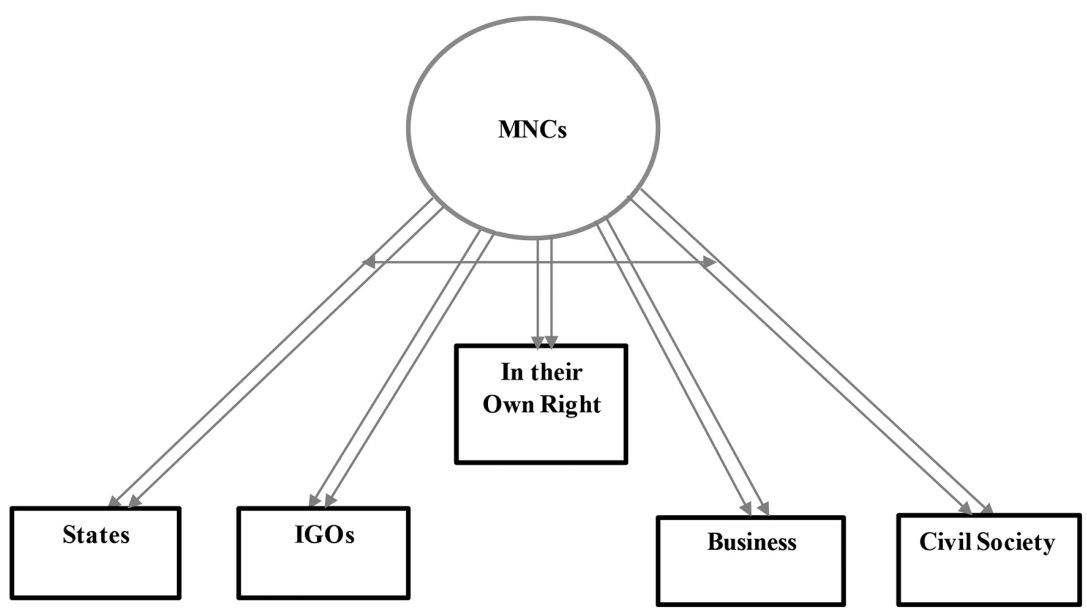

Figure 1.1 Potential pathways of political influence

Using this framework, we contend that MNCs are not simply one out of several actors equally positioned to exert influence in global politics. Instead, they enjoy certain basic privileges in the economy, in society, and in politics that stem from the preponderant position of business in different types of market economies, and from the special role of large corporations in the processes of globalization. This does not suggest that business can expect that other actors will necessarily yield to, or 'obey', corporate demands in respect of interests though. As such, a continuous effort is required to leverage states, IGOs, other sections of business and civil society groups to secure beneficial outcomes. The results of MNCs' political strategies cannot be assumed, and that their 
interests will be served is never guaranteed, as there are many obstacles to the power of MNCs that must be considered as well. Therefore, a careful analysis of the various pathways is required to understand these finer mechanisms.

The contributors to this book help to unpack the complexity of the pathways, and their interactions, to argue that corporations, and MNCs specifically, seek political influence in different stages of decision-making, in different scenarios, at different territorial levels, and through different mechanisms, with variation across policy fields. Hence, different pathways of influence are possible: sometimes a single pathway is preferred, or at least given priority, while sometimes a combination of pathways are taken. The contributors theorize these different pathways and give examples of how they are pursued. Only a few examples from the enormous variation and immense material that is available are considered but based on these cases it is possible to illustrate the key pathways of influence in global politics employed by MNCs. Furthermore, an embedded firm-centered approach is taken. MNCs are examined as general political actors involved in economic and political exchanges in complex institutional environments. Embeddedness, therefore, implies that although we can elucidate some general patterns of MNC behavior, these features must be established on the basis of the variable territorial, sectoral and cultural contexts in which corporations find themselves and that enable or constrain the pathways of influence.

In Chapter 2, 'Globalizing State Capitalism? Selective Internationalization of MNCs from Emerging Economies', Christian May argues that the ability of MNCs to shape global operations can be used as an indicator of their power. Indeed, they are able to use this structural power to influence global politics. In this sense, large firms from emerging economies might not appear as global as their Western peers. This is due to their limited capital base and different insertion into global value chains. However, on closer inspection, it is the particular relationship between MNCs and their home states that shapes the internationalizing efforts by emerging economies' MNCs. This political aspect is often overlooked and, hence, understated. The chapter looks at the corporate sector in Brazil and India to shed light on the connections.

In Chapter 3, 'MNCs and State Infrastructural Power', Linda Weiss and Elizabeth Thurbon examine the extraordinary capacity of the modern state with regard to its pre-industrial predecessor. They consider why and how some states are able to execute their decisions and pursue their ambitions. Focusing on the US, they show that its economic power may seem stronger than ever, ostensibly bolstered by being home to the world's most globalized companies. However, the strength of US MNCs may have contradictory consequences. By internationalizing its infrastructural power, the US has achieved significant benefits for its MNCs by extending national intellectual property rules into foreign jurisdictions. Yet, by the same actions, the US has fostered the con- 
ditions that have been steadily diminishing the state's infrastructural power at home.

In Chapter 4, 'Corporate Influence and Environmental Regulation in Shipping: Navigating Norms and Influence Pathways in the International Maritime Organization', Christian Hendriksen examines the role of MNCs in the regulation of international shipping. First, the chapter explains how the structure of the maritime industry and the regulatory framework provides the basis for MNCs as political actors. Second, the chapter shows how this translates into MNCs' influence in the International Maritime Organization (IMO), which is the designated UN agency tasked with regulating the industry. Third, the chapter explores how the role of MNCs in the IMO relates to the relationship between MNCs and individual states and what lessons we can draw from MNCs' political activities in international shipping.

As analyzed by Kate Macdonald in Chapter 5, 'Private Sustainability Governance and Global Corporate Power', the social and environmental impacts of global business are regulated by an array of schemes. These include labels such as Fairtrade, Rainforest Alliance and the Forest Stewardship Council, alongside multi-stakeholder roundtables and working groups. While these schemes are lauded as innovative tools for promoting global sustainability norms, others perceive them as tools that reproduce global corporate power and insulate companies from societal pressure. Studying schemes in the agribusiness and forestry sectors, the chapter theorizes and illustrates sources and pathways of global corporate influence, and the contested political processes through which the legitimacy of corporate power is asserted and resisted.

Business is often portrayed as consisting of individual firms without a capacity to develop relevant collective action, but in Chapter 6, 'MNCs and their Role in Global Business Associations', Karsten Ronit shows that MNCs acting through national associations can participate in a range of leading business associations at the global level. In general, global peak associations are concerned with representing the broad interests of business and draw on national associations as members. However, in different contexts, peak associations admit single corporations as members. Direct membership offers stronger opportunities for MNC influence in some organizations, a practice that has grown stronger, but still these changes do not alter the big picture.

In Chapter 7, 'The Power of Mining MNCs: Global Governance and Social Conflict', Lian Sinclair analyzes how mining MNCs pursue their interests through social and political strategies across political scales, and how they respond to social conflict and challenges to their legitimacy from people affected by mining and their civil society allies. Using data from Rio Tinto's Kelian mine in Indonesia, she shows how local concerns 'jumped scales' when activists created alliances with national and international civil society groups. In response, mining MNCs established a network of global business associa- 
tions and governance standards that emphasize consultation and participation. Mechanisms based on these standards seek to contain and re-localize conflict through participation.

In Chapter 8, 'Knowledge and Power: The Role of the Big Four in in the Competitive Disharmonization of Global Corporate Tax Avoidance Regulations', Ainsley Elbra, John Mikler and Hannah Murphy-Gregory scrutinize how the Big Four professional services firms (PwC, Deloitte, KPMG and EY) promote, sanction, and regularize the behavior of other MNCs as well as governments. Their services are neither purely technical nor neutral because they construct and enhance the legitimacy and discursive power of MNCs. This chapter looks at their role in facilitating and discursively defending global corporate tax avoidance, and it shows that MNCs use their ability to operate across multiple jurisdictions to take advantage of opportunities to reduce or eliminate their taxation obligations.

Finally, in Chapter 9, we bring together the different findings and explain the general pathways through which MNCs seek influence in global politics. We show that this influence is not restricted to traditional arenas of policy-making but also encompasses multiple actors and relations that are intrinsically entangled. Arguing for a much-needed synthesis in the study of MNC engagement in politics, we demonstrate how different approaches in the social sciences can be improved via a more holistic approach.

MNCs and their pathways of political influence in global politics is a huge theme. We have consulted different literatures that can guide our study and many insights can be helpful. Various disciplines and subdisciplines, however, have tended to identify particular modes of corporate action and sidestepped others, but it is important that we recognize the complexity of MNCs and synthesize these into a general framework for analysis. This is an ambitious endeavor, but we are attempting it because we believe that a holistic approach is necessary to capture the diverse actions of corporations in general, and MNCs specifically, and the different mechanisms of influence they employ. The traditional focus on single and separate pathways can yield important insights but cannot fully grasp their complex role in global politics. A substantial number of cases and issues must be examined to distill some general patterns of MNC behavior, and we cannot complete such a project here. But we can begin this venture by devising some principal elements for an analytical framework applied by the contributors to this volume.

\section{NOTES}

1. As per President Clinton's campaign in the 1990s.

2. We deliberately use this term because the term 'non-governmental organization', which is often used, explicitly refers only to those that are non-government, and, 
in principle, includes organizations representing interests in both the market and civil society.

3. More specifically, Smith's invisible hand was not the basis for competition but the concept of a mechanism where the pursuit of enlightened self-interest led to the unwitting advancement of the common good.

\section{REFERENCES}

Abbott, K.W. and D. Snidal (2009), 'The governance triangle: regulatory standards institutions and the shadow of the state', in W. Mattli and N. Woods (eds), The Politics of Global Regulation, Princeton, NJ: Princeton University Press, pp. 44-88.

Bachrach, P. and M. Baratz (1962), 'Two faces of power', American Political Science Review, 56(4), 947-52.

Banks Around the World (2018), 'Top 100 banks in the world', accessed 30 August 2019 at http://www.relbanks.com/worlds-top-banks/assets.

Barkan, J. (2013), Corporate Sovereignty: Law and Government Under Capitalism, Minneapolis, MN: University of Minnesota Press.

Barnett, M. and R. Duvall (2005), 'Power in international politics', International Organization, 59(1), 39-75.

Beck, T., D. Kunt and R. Levine (2005), 'Bank concentration and fragility: impact and mechanics', NBER Working Papers, No. 11500, accessed 10 June 2014 at http:// www.nber.org/papers/w11500.

Bloomfield, M.J. (2017), Dirty Gold: How Activism Transformed the Jewelry Industry, Boston, MA: MIT Press.

Bonturi, M. and K. Fukasaku (1993), 'Globalisation and intra-firm trade: an empirical note', OECD Economic Studies, No. 20, 145-59.

Bowen, F. and J.A. Aragon-Correa (2014), 'Greenwashing in corporate environmentalism research and practice: the importance of what we say and do', Organization \& Environment, 27(2), 107-12.

Braithwaite, J. and P. Drahos (2000), Global Business Regulation, Cambridge, UK: Cambridge University Press.

Broome, A. (2014), Issues and Actors in the Global Political Economy, Basingstoke: Palgrave Macmillan.

Bryant, R.L. and S. Bailey (1997), Third World Political Ecology, Abingdon/New York: Routledge.

Büthe, T. and W. Mattli (2011), The New Global Rulers: The Privatization of Regulation in the World Economy, Princeton, NJ: Princeton University Press.

Cahill, D. (2014), The End of Laissez Faire? On the Durability of Embedded Neoliberalism, Cheltenham, UK and Northampton, MA, USA: Edward Elgar Publishing.

Cerny, P. (2000), 'Political globalization and the competition state', in R. Stubbs and G. Underhill (eds), Political Economy and the Changing Global Order, Oxford: Oxford University Press.

Cerny, P. (2010), 'The competition state today: from raison d'État to raison $d u$ Monde', Policy Studies, 31(1), 5-21.

Chang, H. (2008), Bad Samaritans: The Myth of Free Trade and the Secret History of Capitalism, New York: Bloomsbury Press.

Clapp, J. (1998), 'The privatization of global environmental governance: ISO 14000 and the developing world', Global Governance, 4(3), 295-316. 
Clapp, J. (2005), 'Transnational corporations and global environmental governance', in P. Dauvergne (ed.), Handbook of Global Environmental Politics, Cheltenham, UK and Northampton, MA, USA: Edward Elgar Publishing, pp. 284-97.

Cox, R.W. (1987), Production, Power and World Order: Social Forces in the Making of History, New York: Columbia University Press.

Crouch, C. (2011), The Strange Non-Death of Neoliberalism, Cambridge, UK: Polity Press.

Culpepper, P.D. (2011), Quiet Politics and Business Power: Corporate Control in Europe and Japan, Cambridge, UK: Cambridge University Press.

Cumbers, A., C. Nativel and P. Routledge (2008), 'Labour agency and union positionalities in global production networks', Journal of Economic Geography, 8, 369-87.

Dahl, R. (1957), 'The concept of power', Behavioral Science, 2, 201-15.

Dauvergne, P. and G. LeBaron (2014), Protest Inc.: The Corporatization of Activism, Cambridge, UK: Polity Press.

Davies, A. (2015), 'CSG industry hires well-connected staffers', Sydney Morning Herald, 25 May, accessed 22 July 2015 at http://www.smh.com.au/nsw/csg-industry -hires-wellconnected-staffers-20150524-gh2rg3.html.

Eccleston, R. and A. Elbra (2018), Business, Civil Society and the New Politics of Corporate Tax Justice: Paying a Fair Share?, Cheltenham, UK and Northampton, MA, USA: Edward Elgar Publishing.

Financial Times (2016), 'FT Global 500 2015', accessed 5 June 2016 at www.ft.com/ $\mathrm{ft} 500$.

Fortune (2019), Fortune Global 500, accessed 3 September 2020 at http://fortune.com/ global500/2019/

Frank, A.G. (1978), Dependent Accumulation and Underdevelopment, London: Macmillan.

Friedman, T. (2000), The Lexus and the Olive Tree, revised edition, London: HarperCollins.

Fuchs, D. (2007), Business Power in Global Governance, Boulder, CO: Lynne Rienner Publishers.

Funk, R.J. and D. Hirschman (2015), 'Beyond nonmarket strategy: market actions as corporate political activity', Academy of Management Review, 42(1), 32-52.

Greif, A. (2005), 'Commitment, coercion and markets: the nature and dynamics of institutions supporting exchange', in C. Ménard and M.M. Shirley (eds), Handbook of New Institutional Economics, Dordrecht: Springer, pp. 727-888.

Gunningham, N. and D. Sinclair (2002), Leaders and Laggards: Next Generation Environmental Regulation, Sheffield: Greenleaf Publishing.

Hale, T. and D. Held (eds) (2011), The Handbook of Transnational Governance: Institutions and Innovations, Cambridge, UK: Polity.

Hall, P.A. and D. Soskice (eds) (2001), Varieties of Capitalism: The Institutional Foundations of Comparative Advantage, Oxford: Oxford University Press.

Harrod, J. (2006), 'The century of the corporation', in C. May (ed.), Global Corporate Power, Boulder, CO: Lynne Rienner Publishers, pp. 23-46.

Haufler, V. (2000), 'Private sector international regimes', in R. Higgott, G. Underhill and A. Bieler (eds), Non-state Actors and Authority in the Global System, Abingdon/ New York: Routledge, pp. 121-37.

Hay, C. (2019), 'Does capitalism (still) come in varieties?', Review of International Political Economy, 27(2), 302-19.

Hillman, A.J., G.D. Keim and D. Schuler (2004), 'Corporate political activity: a review and research agenda', Journal of Management, 30(6), 837-57. 
Hollingsworth, J.R. and R. Boyer (1997), 'Coordination of economic actors and social systems of production', in J.R. Hollingsworth and R. Boyer (eds), Contemporary Capitalism: The Embeddedness of Institutions, Cambridge, UK: Cambridge University Press, pp. 1-48.

International Monetary Fund (2015), ‘April 2015 edition', World Economic Outlook Database, accessed 12 January 2016 at http://www.imf.org/external/pubs/ft/weo/ 2015/01/weodata/index.aspx.

International Organization for Standardization [ISO] (2016a), 'Members', accessed 4 August 2020 at http://www.iso.org/iso/home/about/iso_members.htm?membertype =membertype_MB.

International Organization for Standardization [ISO] (2016b), 'ANSI, United States', accessed 4 August 2020 at http://www.iso.org/iso/home/about/iso_members/iso member body.htm?member id=2188.

Karliner, J. (1997), The Corporate Planet: Ecology and Politics in the Age of Globalization, San Francisco, CA: Sierra Club.

Kelly, D. (2005), 'The International Chamber of Commerce', New Political Economy, 10(2), 259-71.

Kollman, K. (2008), 'The regulatory power of business norms: a call for a new research agenda', International Studies Review, 10(3), 397-419.

Korten, D. (2015), When Corporations Rule the World, 3rd edition, Oakland, CA: Berrett-Koehler Publishers.

Kozlowski, A., C. Searcy and M. Bardecki (2015), 'Corporate sustainability reporting in the apparel industry', International Journal of Productivity and Performance Management, 64(3), 377-97.

Lambin, E.F. and T. Thorlakson (2018), 'Sustainability standards: interactions between private actors, civil society, and governments', Annual Review of Environment and Resources, 43(1), 369-93.

Lawton, T., S. McGuire and T. Rajwani (2013), 'Corporate political activity: a literature review and research agenda', International Journal of Management Reviews, 15(1), 86-105.

Lawton, T. and T.S. Rajwani (2015), The Routledge Companion to Non-Market Strategy, Abingdon/New York: Routledge.

LeBaron, G. (2014), 'Subcontracting is not illegal, but is it unethical? Business ethics, forced labor, and economic success', Brown Journal of World Affairs, 20(2), 237-49.

Levitt, T. (1983), 'The globalization of markets', Harvard Business Review, 61(3), 92-102.

Levy, D.L. and P.J. Newell (2002), 'Business strategy and international environmental governance: towards a neo-Gramscian synthesis', Global Environmental Politics, 2(4), 84-101.

Lindblom, C. (1977), Politics and Markets, New York: Basic Books.

Lukes, S. (1974), Power: A Radical View, London: Palgrave Macmillan.

Mikler, J. (2018), The Political Power of Global Corporations, Cambridge, UK: Polity Press.

Moffat, K. and A. Zhang (2014), 'The paths to social license to operate: an integrative model explaining community acceptance of mining', Resources Policy, 39, 61-70.

Morgan, G., A. Sturdy and M. Frenkel (2019), 'The role of large management consultancy firms in global public policy', in D. Stone and K. Moloney (eds), The Oxford Handbook of Global Policy and Transnational Administration, Oxford: Oxford University Press. 
Nolan, P., D. Sutherland and J. Zhang (2002), 'The challenge of the global business revolution', Contributions to Political Economy, 21(1), 91-110.

Olson, M. (1965), The Logic of Collective Action: Public Goods and the Theory of Groups, Cambridge, MA: Harvard University Press.

Organisation for Economic Co-operation and Development [OECD] (2011), Bank Competition and Financial Stability, accessed 4 August 2020 at http://www.oecd .org/finance/financial-markets/48501035.pdf.

Organisation for Economic Co-operation and Development [OECD] (2014), 'Concentration of the banking sector: assets of three largest banks as a share of assets of all commercial banks, percent, 2011', OECD Economic Surveys: Netherlands 2014, accessed 4 August 2020 at https://read.oecd-ilibrary.org/economics/oecd -economic-surveys-netherlands-2014/concentration-of-the-banking-sector_eco surveys-nld-2014-graph31-en\#page1.

Palan, R., R. Murphy and C. Chavagneux (2010), Tax Havens: How Globalization Really Works, Ithaca, NY: Cornell University Press.

Porter, T. and K. Ronit (2015), 'Implementation in international business self-regulation: the importance of sequences and their linkages', Journal of Law and Society, 42(3), 413-33.

Ramus, C.A. and I. Montiel (2005), 'When are corporate environmental policies a form of greenwashing?', Business and Society, 44(4), 377-414.

Rixen, T. (2011), 'From double tax avoidance to tax competition: explaining the institutional trajectory of international tax governance', Review of International Political Economy, 18(2), 197-227.

Roberts, S., J.P. Jones III and O. Fröhling (2005), 'NGOs and the globalization of managerialism: a research framework', World Development, 33(11), 1845-64.

Ronit, K. (2007), 'Introduction: the new policy arrangements of business and countervailing groups', in K. Ronit (ed.), Global Public Policy: Business and the Countervailing Powers of Civil Society, Abingdon/New York: Routledge, pp. 1-14.

Ronit, K. (2016), 'Global employer and business associations: their relations with members in the development of mutual capacities', European Review of International Studies, 3(1), 53-77.

Ronit, K. (2018), Global Business Associations, Abingdon/New York: Routledge.

Ruggie, J.G. (2013), Just Business: Multinational Corporations and Human Rights, New York: W.W. Norton \& Company.

Rugman, A. (2000), The End of Globalization, London: Random House Business Books.

Rugman, A. and A. Verbeke (2009), 'Location, competitiveness, and the multinational enterprise', in A. Rugman (ed.), The Oxford Handbook of International Business, 2nd edition, Oxford: Oxford University Press.

Scholte, J. (2005), Globalisation: A Critical Introduction, 2nd edition, Basingstoke: Palgrave Macmillan.

Schwartz, H. (2000), States versus Markets, 2nd edition, Basingstoke: Palgrave Macmillan.

Seitz, K. and J. Martens (2017), 'Philanthrolateralism: private funding and corporate influence in the United Nations', Global Policy, 8(5), 46-50.

Sell, S. (2003), Private Power, Public Law: The Globalization of Intellectual Property Rights, Cambridge, UK: Cambridge University Press.

Smith, A. (1776 [2003]), The Wealth of Nations, New York: Bantam Classic.

Staples, C.L. (2007), 'Board globalisation in the world's largest TNCs 1993-2005', Corporate Governance, 15(2), 311-21. 
Stevis, D. and R. Felli (2015), 'Global labour unions and just transition to a green economy', International Environmental Agreements: Politics, Law and Economics, 15(1), 29-43.

Stone, D. and K. Moloney (eds) (2019), The Oxford Handbook of Global Policy and Transnational Administration, Oxford: Oxford University Press.

Strange, S. (1988), States and Markets, London/New York: Continuum.

Streeck, W. (2011), 'Taking capitalism seriously: towards an institutionalist approach to contemporary political economy', Socio-Economic Review, 9(1), 137-67.

Suchman, M.C. (1995), 'Managing legitimacy: strategic and institutional approaches', Academy of Management Review, 20(3), 571-610.

Teeple, G. and S. McBride (eds) (2011), Relations of Global Power: Neoliberal Order and Disorder, Toronto: University of Toronto Press.

Tepper, J. and D. Hearn (2019), The Myth of Capitalism: Monopolies and the Death of Competition, Hoboken, NJ: Wiley.

Tienhaara, K. (2014), 'Corporations: business and industrial influence', in P.G. Harris (ed.), Routledge Handbook of Global Environmental Politics, Abingdon/New York: Routledge.

Toffel, M.W., J.L. Short and M. Ouellet (2015), 'Codes in context: how states, markets, and civil society shape adherence to global labor standards', Regulation and Governance, 9(3), 205-23.

United Nations (1945), Charter of the United Nations and Statute of the International Court of Justice, San Francisco, CA: United Nations.

United Nations Conference on Trade and Development [UNCTAD] (2011), 'Web table 34: number of parent corporations and foreign affiliates, by region and economy 2010' in UNCTAD (ed.), World Investment Report 2011, accessed 20 July 2015 at https://unctad.org/Sections/dite_dir/docs/WIR11_web\%20tab\%2034.pdf.

United Nations Conference on Trade and Development [UNCTAD] (2014), 'Web table 28: the world's top 100 non-financial TNCs, ranked by foreign assets 2013' in UNCTAD (ed.), World Investment Report 2014, accessed 20 October 2015 at http:// unctad.org/Sections/dite_dir/docs/WIR2014/WIR14_tab28.xls.

van der Pijl, K. (1998), Transnational Classes and International Relations, Abingdon/ New York: Routledge.

van Veen, K. and I. Marsman (2008), 'How international are executive boards of European MNCs? National diversity in 15 European countries', European Management Journal, 26(3), 188-98.

Vaughan, A. (2014), 'Lego ends Shell partnership following Greenpeace campaign', The Guardian, accessed 25 August 2020 at https://www.theguardian.com/environment/ 2014/oct/09/lego-ends-shell-partnership-following-greenpeace-campaign.

Vogel, D. (2005), The Market for Virtue: The Potential and Limits of Corporate Social Responsibility, Washington, DC: Brookings Institution Press.

Voss, H. (2013), 'The global company', in J. Mikler (ed.), The Handbook of Global Companies, Oxford: Wiley-Blackwell, pp. 19-34.

Walmart (2013), One Mission: Save Money. Live Better. Walmart 2103 Annual Report, accessed 18 April 2017 at https://s2.q4cdn.com/056532643/files/doc financials/ 2013/Annual/2013-annual-report-for-walmart-stores-inc_130221024708579502 .pdf.

Walmart (2017), 'Apply to be a supplier', accessed 18 April 2017 at http://corporate .walmart.com/suppliers/apply-to-be-a-supplier.

Wilks, S. (2013), The Political Power of the Business Corporation, Cheltenham, UK and Northampton, MA, USA: Edward Elgar Publishing. 
Windsor, D. (2007), 'Toward a global theory of cross-border and multilevel corporate political activity', Business and Society, 46(2), 253-78.

World Bank (2019), 'Gross domestic product 2018', World Development Indicator Database, 1 July, accessed 30 August 2019 http://databank.worldbank.org/data/ download/GDP.pdf.

Yaziji, M. and J. Doh (eds) (2009), NGOs and Corporations: Conflict and Collaboration, Cambridge, UK: Cambridge University Press.

Zadek, S. (2013), 'Will business save the world?', in J. Mikler (ed.), The Handbook of Global Companies, Oxford: Wiley-Blackwell, pp. 474-91. 